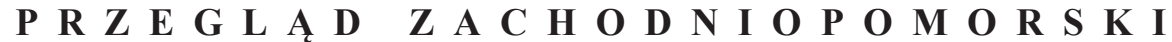 ROCZNIK XXX (LIX) ROK 2015 ZESZYT 1
}

$\begin{array}{llllllllllllllll}\mathbf{S} & \mathbf{T} & \mathbf{U} & \mathbf{D} & \mathbf{I} & \mathbf{A} & & \mathbf{I} & \mathbf{R} & \mathbf{O} & \mathbf{Z} & \mathbf{P} & \mathbf{R} & \mathbf{A} & \mathbf{W} & \mathbf{Y}\end{array}$

\author{
Adam AndrZej Urbanowicz \\ Gorzów Wielkopolski
}

\section{Propaganda OSIĄgnięć SPÓŁdZIELNi PRODUKCYJNYCH I PAŃSTWOWYCH GOSPODARSTW ROLNYCH NA LAMACH CZASOPISMA „GŁos SzCZECIŃSKI” DO 1956 ROKU. Z DZIEJÓW KOMUNISTYCZNEJ INDOKTRYNACJI polskiego spoleczeństwa na Pomorzu Zachodnim}

Słowa kluczowe: propaganda, kolektywizacja, Pomorze Zachodnie

Keywords: propaganda, collectivisation, West Pomerania

Rok 1948 był przełomem w dziejach Polski Ludowej'. W pierwszych latach po drugiej wojnie światowej komuniści starali się ukrywać swoje prawdziwe intencje. Propaganda ukazywała Związek Radziecki jako sojusznika, ale nie zapowiadano naśladowania wszystkich przyjętych tam rozwiązań ustrojowych i społeczno-gospodarczych. W szczególności nie było mowy o kolektywizacji rolnictwa. Sytuacja uległa zmianie po posiedzeniu Biura Informacyjnego Partii Komunistycznych i Robotniczych w Bukareszcie z czerwca 1948 roku. Władze krajów demokracji ludowej wezwano na nim do przeprowadzenia kolektywizacji wsi. Na plenum Komitetu Centralnego Polskiej Partii Robotniczej (KC PPR) z sierpnia-września 1948 roku zainicjowano nową politykę wobec polskiego rolnictwa².

\footnotetext{
${ }^{1}$ J. Kaliński, Forsowna kolektywizacja rolnictwa (1948-1956), „Kwartalnik Historyczny” 1984, nr 1, s. 111.

2 B. Dymek, PZPR 1948-1954, Warszawa 1989, s. 235; J. Kaliński, Forsowna kolektywizacja..., s. 113; M. Nadolski, Komuniści wobec chłopów w Polsce 1941-1956. Mity i rzeczywistość, Warszawa 1993, s. 205; M.E. Ożóg, Władysław Gomułka. Biografia polityczna, t. 1, Warszawa 1989, s. 207.
} 
Za cel uznano tworzenie spółdzielni produkcyjnych. W 1949 roku opracowano statuty dla trzech typów spółdzielczych gospodarstw: Zrzeszeń Uprawy Ziemi $(\mathrm{ZUZ})^{3}$, Rolniczych Spółdzielni Wytwórczych (RSW)4 i Rolniczych Zespołów Spółdzielczych $(\mathrm{RZS})^{5}$. Rozpoczął się okres kolektywizacji rolnictwa, który trwał aż do VIII plenum KC Polskiej Zjednoczonej Partii Robotniczej w październiku 1956 roku, kiedy to przeprowadzono wielką kampanię propagandową wychwalającą zalety zespołowej gospodarki. Przedstawiano w niej nie tylko sukcesy gospodarstw spółdzielczych, lecz także państwowych gospodarstw rolnych. W kampanii uczestniczyły czasopisma PPR, a potem PZPR. Szczecińskim organem prasowym tej partii był wówczas „Głos Szczeciński”. Pierwszy numer czasopisma ukazał się 31 marca 1949 roku, jednak nie jest to rzeczywisty początek historii tego periodyku. Wcześniej wydawano bowiem dziennik zatytułowany „Szczeciński Głos Ludu”. Jego pierwszy numer ukazał się w 19 czerwca 1947 roku i ta data traktowana jest jako początek dziejów „Głosu Szczecińskiego”. Czasopismo to stanowiło mutację organu KC PPR - „Głos Ludu” - i wydawane było w Warszawie7. W 1949 roku „Głos Szczeciński” był już samodzielnym

${ }^{3} \mathrm{O}$ zasadach, na jakich miały funkcjonować ZUZ, zob. szerzej: D. Jarosz, Polityka władz komunistycznych w Polsce w latach 1948-1956 a chłopi, Warszawa 1998, s. 23; J. Kaliński, Forsowna kolektywizacja..., s. 121.

${ }^{4} \mathrm{O}$ zasadach, na jakich miały funkcjonować RSW, zob. szerzej D. Jarosz, Polityka władz..., s. 24; J. Kaliński, Forsowna kolektywizacja..., s. 121.

${ }^{5} \mathrm{O}$ zasadach, na jakich miały funkcjonować RZS, zob. szerzej D. Jarosz, Polityka władz..., s. 25; J. Kaliński, Forsowna kolektywizacja..., s. 122.

${ }^{6}$ Nakład tego dziennika 19.06 .1947 r. to 7 tys. egz. T. Białecki, Czasopiśmiennictwo polskie na Pomorzu Zachodnim w latach 1945-1949, „Przegląd Zachodniopomorski” 1968, z. 4, s. 122; T. Białecki, Prasa szczecińska, w: 25 lat prasy na ziemiach zachodnich i pótnocnych, Kraków 1972, s. 86; T. Białecki, Rozwój prasy partyjnej PPR i PZPR w województwie szczecińskim w latach 1945-1972, „Przegląd Zachodniopomorski” 1972, z. 3, s. 187; T. Białecki, Prasa Pomorza Szczecińskiego w latach 1945-1975, Szczecin 1978, s. 18; K. Kozłowski, Środki masowego przekazu w Szczecinie w latach 1945-1990, w: Stowem i piórem. 50 lat dziennikarstwa na Pomorzu Zachodnim, red. T. Białecki, Szczecin 1996, s. 17-32; E. Krasucki, Poczatki „Głosu Szczecińskiego” w świetle dokumentów z lipca 1947 roku, „Przegląd Zachodniopomorski” 2005, z. 3, s. 157; S. Pawłowicz, 40 lat! Głos Szczeciński. Dziennik Polskiej Zjednoczonej Partii Robotniczej 1947-1987, Szczecin 1987, s. 5; L. Springer, Życie gospodarcze regionu szczecińskiego na łamach „Głosu Szczecińskiego” w jego ostatnim stalinowskim okresie, „Przegląd Zachodniopomorski” 2002, z. 3, s. 39.

${ }^{7}$ Materiały przesyłano z Warszawy dalekopisem. S. Pawłowicz, 40 lat!..., s. 10; L. Springer, Życie gospodarcze..., s. 39 . 
organem Komitetu Wykonawczego PZPR, dziennik drukowano w Szczecinie ${ }^{8}$, a pierwszym redaktorem naczelnym był Stanisław Szydłowski ${ }^{9}$.

Nie był jednak „Szczeciński Głos Ludu” w ogóle pierwszym czasopismem, które przeznaczone było dla mieszkańców polskiego Szczecina. Już 7 października 1945 roku ukazał się periodyk „Kurier Szczeciński” ${ }^{\prime 0}$. Był to pierwszy w tym mieście dziennik. Wydawała go Spółdzielnia Wydawnicza „Czytelnik”, a jego redaktorem naczelnym był Mieczysław Halski. „Kurier Szczeciński” realizował naturalnie polityczne dyrektywy PPR i PZPR, ale jak zauważył Kazimierz Kozłowski, nie był: „główną tubą propagandową partii"l1. Propaganda partyjna była bowiem prowadzona przede wszystkim na łamach czasopisma „Głos Szczeciński" ${ }^{12}$. To ten dziennik propagował współzawodnictwo pracy i sukcesy zarówno spółdzielni produkcyjnych, jak i państwowych gospodarstw rolnych ${ }^{13}$. Upowszechniano $\mathrm{w}$ nim tezy partyjnej propagandy w reportażach (autorstwa dziennikarzy i chłopskich korespondentów), komentarzach oraz relacjach z narad władz partyjnych i państwowych różnych szczebli.

W artykule pokazano, jak próbowano na łamach „Głosu Szczecińskiego” propagować ideę socjalistycznych przeobrażeń na wsi zachodniopomorskiej. Ukazano w nim główne problemy poruszane w artykułach poświęconych funkcjonowaniu tak spółdzielni produkcyjnych, jak i państwowych gospodarstw rolnych $^{14}$.

${ }^{8}$ Drukowano go w zakładzie graficznym Pod Bramą 7 w formacie berlińskim $(31,5$ x $47 \mathrm{~cm})$. W 1954 r. druk przeniesiono do zakładu przy alei Wojska Polskiego 128. Od tej pory druk w formacie polskim (35,3 x 49,5 cm), S. Pawłowicz, 40 lat!..., s. 10.

${ }^{9}$ Czasopismem kierował początkowo Stanisław Szydłowski, który wcześniej związany był z „Kurierem Szczecińskim”. Zdaniem Eryka Krasuckiego, S. Szydłowski mógł zawdzięczać swoją karierę znajomości z Jerzym Borejszą, E. Krasucki, Początki „Głosu Szczecińskiego”..., s. 157-158. Komitet redakcyjny tworzyli: Antoni Perłowski, Józef Baran, Kazimierz Błahij i Zenon Dmochowski, T. Białecki, Prasa szczecińska..., s. 87.

${ }^{10}$ Jego nakład to 3 tys. egz., T. Białecki, Czasopiśmiennictwo polskie..., s. 122; T. Białecki, Prasa szczecińska..., s. 84; T. Białecki, Rozwój prasy..., s. 187; T. Białecki, Prasa Pomorza Szczecińskiego..., s. 18; K. Kozłowski, Środki masowego..., s. 18.

${ }^{11}$ K. Kozłowski, Środki masowego..., s. 18.

12 Jak zauważyła Lucyna Springer w artykułach publikowanych na łamach „Głosu Szczecińskiego": posuwano się do fatszowania i naciagania faktów, L. Springer, Życie gospodarcze..., s. 67.

${ }^{13}$ Ibidem, s. 50.

${ }^{14}$ Sprawa PGR-ów łączyła się z kwestią spółdzielni produkcyjnych. Dariusz Jarosz wskazywał, jak bardzo zła opinia na temat funkcjonowania majątków państwowych przyczyniała się do niechęci chłopów wobec spółdzielni produkcyjnych, D. Jarosz, Polityka władz..., s. 65. 
Na łamach „Głosu Szczecińskiego" informowano chętnie o powstawaniu nowych spółdzielni. Ich duża liczba miała stanowić o sukcesie socjalistycznych przeobrażeń na wsi ${ }^{15}$. W rzeczywistości wiele spółdzielni produkcyjnych powstawało w warunkach dalekich od dobrowolności. Symbolem nadużyć w procesie kolektywizacji stały się tak zwane wydarzenia gryfickie (luty-marzec 1951 r.) ${ }^{16}$. Doszło wtedy do działań o charakterze przestępczym ze strony przedstawicieli aparatu partyjnego i państwowego, dążącego do zwiększenia za wszelką cenę liczby spółdzielni produkcyjnych oraz wymuszenia na chłopach sprzedaży zboża. Nadużycia przybrały takie rozmiary, że zostały potępione uchwałą Biura Politycznego KC PZPR ${ }^{17}$. Miejscowi działacze musieli wygłosić samokrytykę ${ }^{18}$. W rzeczywistości przemoc stosowana wobec chłopów nie wynikała tylko z samowoli miejscowego aktywu. Była ona spowodowana koniecznością złamania zaciekłego oporu ze strony rolników indywidualnych przed przystępowaniem do spółdzielni produkcyjnych. Jak zauważył Bartosz Kaliski, traktowali oni kolektywizację jako kataklizm ${ }^{19}$. Spółdzielnie produkcyjne rolnikom indywidualnym kojarzyły się słusznie z radzieckimi kołchozami. Komunistyczna propaganda

15300 spółdzielni produkcyjnych w województwie szczecińskim, „Głos Szczeciński” wyd. C, 29.01.1951, nr 28, s. 1; Tapdalanie weszli na nowa droge, „Głos Szczeciński” wyd. C, 1.08.1952, nr 183, s. 4; W 428 gromadach województwa szczecińskiego chłopi gospodaruja zespołowo, „Głos Szczeciński” wyd. C, 25.08.1952, nr 203, s. 3; E. Możejko, Zrodzona w atmosferze radości, „Głos Szczeciński” wyd. C, 31.10.1952, nr 261, s. 3; 500-na spółdzielnia produkcyjna ziemi szczecińskiej RZS ,Droga do socjalizmu” powstała w Janikowie, „Głos Szczeciński” wyd. C, 2.02.1953, nr 29, s. 1; 675 w naszym województwie!, „Głos Szczeciński” wyd. C, 13.05.1954, nr 112, s. 1; W TRZEBÓRZU postanowili gospodarzyć wspólnie. 691 w naszym województwie, „Głos Szczeciński” wyd. C, 29.06.1954, nr 152, s. 1; Wszyscy uczciwi chłopi-członkami spółdzielni. Na przykładzie powiatu stargardzkiego, „Głos Szczeciński” wyd. C, 24.08.1954, nr 200, s. 3. Informowano także o powstaniu nowych spółdzielni produkcyjnych na Dolnym Śląsku. L. Springer, Życie gospodarcze..., s. 51.

${ }^{16}$ J. Kaliński, Forsowna kolektywizacja..., s. 123; B. Kaliski, Przetracić kark kułakowi... terenowy aparat PZPR wobec kolektywizacji rolnictwa, „Przegląd Powszechny” 2000, nr 6, s. 308.

${ }^{17}$ W Protokole z posiedzenia Biura Politycznego KC PZPR z 16 maja 1951 roku była mowa o zrywaniu podłóg w trakcie rewizji, niszczeniu pieców i dobytku chłopów, a w wielu wypadkach „stosowania wobec nich siły fizycznej”. $16 \mathrm{~V} 1951 \mathrm{r}$. Fragmenty protokołu z posiedzeń Biura Politycznego KC PZPR dotyczacego sprawy gryfickiej wraz z załacznikami dotyczacymi tej sprawy, K. Kozłowski, Materiały archiwalne do „Wydarzeń gryfickich” z 1951 r., Szczecin 1992, s. 165; B. Dymek, PZPR 1948-1954..., s. 243.

${ }^{18}$ Wygłosił ją nawet I sekretarz KW PZPR w Szczecinie Jerzy Pryma, 16 V 1951 r. Fragmenty protokotu..., s. 175-185.

${ }^{19}$ B. Kaliski, Przetrącić kark kułakowi..., s. 305. Pisał o tym także D. Jarosz, Polityka władz..., s. 64. 
starała się zmienić negatywne nastawienie polskiego chłopa do radzieckich kołchozów $^{20}$. Nie przyniosło to jednak większych rezultatów.

O ile w wypadku spółdzielni produkcyjnych mogły rozwijać się one przez kolektywizację drobnego rolnictwa, to w odniesieniu do Państwowych Gospodarstw Rolnych (PGR) istotną kwestią było zapewnienie im niezbędnej siły roboczej. W tym kontekście poruszano na łamach „Głosu Szczecińskiego” sprawę zatrudnienia robotników sezonowych ${ }^{21}$.

Wzrost produkcji rolnej był warunkiem poprawy warunków życiowych zarówno w mieście, jak i na wsi. Z tej racji na łamach „Głosu Szczecińskiego” wiele uwagi poświęcano przebiegowi siewów i żniw ${ }^{22}$. Charakterystyczne dla ówczesnej propagandy komunistycznej było to, że odnosząc się do tych pokojowych przecież działań, odwoływano się do retoryki wojennej. Siew i żniwa to czas walki ${ }^{23}$. Wzrost plonów, zgodnie z obowiązującą ideologią, powinno zapewnić wprowadzenie nowych socjalistycznych metod gospodarowania ${ }^{24}$. Stanowił on, według „Głosu Szczecińskiego”, słuszny powód do dumy tak spółdzielców, jak i pracowników PGR-ów. Stąd nie powinno dziwić, że kiedy sekretarz komitetu gminnego PZPR w Wełtyniu Emilia Ziółkowska mówiła o osiągnięciach w 1951 roku, to używała literackich metafor ${ }^{25}$. Potrzeba osiągnięcia lepszych wyników w spółdzielniach i w PGR-ach niż w gospodarstwach indywidualnych wracała

${ }^{20}$ Roman Zambrowski dowodził w referacie wygłoszonym na wojewódzkiej konferencji aktywu spółdzielni produkcyjnych w Szczecinie, że należało wykorzystywać doświadczenia kołchozów w ZSRR, R. Zambrowski, $W$ oparciu o doświadczenia radzieckich kotchoźników usprawnimy gospodarke $w$ istniejacych spółdzielniach produkcyjnych, wzmocnimy wysitki nad dalszym rozwojem socjalistycznej wsi. Referat tow. na wojewódzkiej konferencji aktywu spółdzielni produkcyjnych w Szczecinie, „Głos Szczeciński” wyd. A, 26.06.1950, nr 174, s. 1, 3.

${ }^{21}$ A. Pokorski, Sprawa robotnika sezonowego. Przed akcją siewna w PGR, „Głos Szczeciński” wyd. A, 15.03.1950, nr 74, s. 3; Robotnicy sezonowi w PGR musza znaleźć jak najlepsze warunki życia i pracy, „Głos Szczeciński” wyd. A, 4.06.1950, nr 152, s. 4.

${ }^{22}$ L. Springer, Życie gospodarcze..., s. 51-52.

${ }^{23}$ Przykładem może być fragment tekstu sekretarza Komitetu Wojewódzkiego PZPR Bolesława Nowosada: „Zbliża się kampania żniwna. Mamy trudności w zbiorze siana. Toczy się walka o podniesienie produkcji rolnej, o zwiększenie dostaw chleba, mięsa, mleka", B. Nowosad, PGR - kurs na rentowność, „Głos Szczeciński” wyd. C, 5.07.1956, nr 158, s. 3.

${ }^{24}$ Jak dowodził w wystąpieniu radiowym minister rolnictwa Jan Dąb-Kocioł: „chłopi mimo wrogiej kułackiej propagandy coraz jaśniej widzą, że jedyną drogą usunięcia zacofania gospodarczego i kulturalnego wsi, jedyną drogą osiągnięcia dobrobytu i lepszej przyszłości jest spółdzielczość produkcyjna", cyt. za: Krajowy Zjazd Spółdzielczości Produkcyjnej wytyczy drogę dalszego rozwoju gospodarki zespołowej. Przemówienie radiowe ministra rolnictwa J. Dąb-Kocioła, „Głos Szczeciński” wyd. C, 16.02.1953, nr 41, s. 1.

${ }^{25}$ Weltyń idzie naprzód, „Głos Szczeciński” wyd. BC, 1.01.1952, nr 1, s. 4. 
stale na łamach „Głosu Szczecińskiego”. Jak dowodził Jerzy Pryma - I sekretarz KW PZPR w referacie wygłoszonym 11 stycznia 1951 roku: „Gospodarujące już spółdzielnie muszą stać się żywym przykładem wyższości gospodarki zespołowej nad indywidualną"26. Poprawa efektywności miała być możliwa dzięki wprowadzeniu dniówki obrachunkowej ${ }^{27}$. „Głos Szczeciński” utrzymywał, że istotnie na wielu spółdzielczych polach plony były wyższe niż w gospodarstwach indywidualnych gospodarzy. Tak miało być w 1950 roku w RZS w Smolnicy ${ }^{28}$. „Głos Szczeciński" przekonywał swych czytelników, że wzrost plonów w uspołecznionej gospodarce prowadzi do wzrostu dochodów tak pracowników PGR, jak i spółdzielców ${ }^{29}$. Pisała o tym Maria Cieśla ze spółdzielni Produkcyjnej w Tychwicy (gmina Banie, powiat Gryfino): „Przyjechali do spółdzielni na jednym wozie, niektórzy nawet na wypożyczonym. A dzisiaj nie ma wśród nas nikogo, kto by nie miał choć jednej krowy, a przeważnie mają po dwie" ${ }^{30}$. To właśnie miało skutecznie przekonywać rolników indywidualnych do idei wspólnego gospodarowania $^{31}$. Prawdziwości tej tezy dowodzić miały liczne przykłady. Jan Czumak pisał więc o chłopie, który przystąpił do RZS Zwycięstwo w Sulimie, kiedy stwierdził, że jeden ze spółdzielców zarobił 35 q ziarna i 9 tys. złotych w gotówce. Doszedł bowiem do przekonania, że: „Choćbym ręce po łokcie urobił na indywidualnej

${ }^{26}$ WIEŚ szczecińska na nowym etapie walki o rozwój spółdzielczości produkcyjnej, „Głos Szczeciński” wyd. C, 13.01.1951, nr 12, s. 3. Adam Rapacki podkreślał, że produkcja rolna gospodarki zespołowej powinna rosnąć szybciej niż indywidualnej. A. Rapacki, $W$ stałej ofensywie o rozwój i umacnianie spółdzielczości produkcyjnej. Z przemówienia tow. na Plenum KW PZPR w Szczecinie, „Głos Szczeciński” wyd. C, 20-21.02.1954, nr 43, s. 2.

27 Stosowanie dniówek obrachunkowych przyczynia się do rozwoju spółdzielni i zapewnia wzrost dobrobytu. Po odprawie aktywu spótdzielni produkcyjnych Pomorza Szczecińskiego, „Głos Szczeciński” wyd. A, 16.03.1950, nr 75, s. 3.

${ }^{28}$ S. Pawłowicz, Członkowie RZS w Smolnicy sumuja pótroczne wyniki zespołowej gospodarki, „Głos Szczeciński” wyd. B, 2.12.1950, nr 332, s. 4.

${ }^{29}$ Wysokie plony, wysokie dniówki w większości spółdzielń - to wszystko utwierdza u spótdzielców wiarę w zwycięstwo wspólnej gospodarki, cytat za SPÓŁDZIELNIE pow. stargardzkiego stana się wzorem dobrego gospodarowania, „Głos Szczeciński” wyd. C, 7.03.1952, nr 58, s. 3.

${ }^{30}$ M. Cieśla, Zapraszamy serdecznie na piękna Ziemię Szczecińska do naszej spółdzielni, „Głos Szczeciński” wyd. C, 14.03.1952, nr 64, s. 4.

${ }^{31}$ Indywidualni chtopi będa patrzeć, gdy będziemy dzielić dochody. Wysokość dochodów i sposób podziału winny ich przekonać o wyższości gospodarki zespołowej. REALIZACJA planu 6-letniego w spółdzielczości produkcyjnej-to wzrost dobrobytu pracujących chłopów. Z wojewódzkiej narady przewodniczących spółdzielni produkcyjnych w Szczecinie, „Głos Szczeciński” wyd. C, 22.08.1950, nr 231, s. 3 . 
gospodarce, tylebym nie zapracował"32. Podobne wnioski miał wyciągnąć opisany w artykule opublikowanym na początku lutego 1952 roku indywidualny rolnik z miejscowości Tucze, który stwierdzał, że jego dochód to zaledwie 10124 zł, podczas gdy spółdzielca z tej samej wioski zarobił 20300 zł33. Tego typu przypadki pozwalały Bogdanowi Chocianowiczowi nader optymistycznie oceniać przyszłość spółdzielni produkcyjnych. W jego ocenie: „Chłopski proletariat, który przyszedł, aż tutaj nad Odrę, po ziemie i chleb, znajduje właściwą drogę. Resztki chłopskiego zacofania i nieufności do nowego, ostatnie pozostałości »drugiej duszy« zlikwiduje zwycięski bilans" ${ }^{\text {34 }}$. Rolnicy indywidualni mieli także podziwiać osiągnięcia PGR-ów. Tak właśnie było według reportera w wypadku Zespołu PGR Lubicz wiosną 1952 roku $^{35}$. Rzeczywistość była jednak inna. Jak wskazał Dariusz Jarosz, chłopi przystępowali do spółdzielni produkcyjnych głównie z powodu obciążenia ich gospodarstw obowiązkowymi dostawami produktów rolnych i wysokimi podatkami ${ }^{36}$.

Na łamach „Głosu Szczecińskiego” pisano wiele o współzawodnictwie pra$\mathrm{cy}^{37}$, które miano wprowadzić zarówno w PGR-ach ${ }^{38}$, jak i w spółdzielniach pro-

32 J. Czumak, Zwycięstwo spółdzielców Sulimierza, „Głos Szczeciński” wyd. C, 22.01.1952, nr 19, s. 3. s. 4.

${ }^{33}$ Dwa bilanse. Na przykładzie gromady Tucze, „Głos Szczeciński” wyd. C, 1.02.1952, nr 28,

${ }^{34}$ B. Chocianowicz, Przyszli do „Lepszego Życia”, „Głos Szczeciński” wyd. C, 9-10.02.1952, nr 35, s. 3.

${ }^{35}$ Ten zespół zdaniem reportera zasługiwał na radziecką nazwę: Zespół-Gigant. Bo my jesteśmy PGR-em socjalistycznym gospodarstwem..., „Głos Szczeciński” wyd. BC, 31.03.1952, nr 78, s. 3.

${ }^{36}$ D. Jarosz, Polityka władz..., s. 106.

${ }^{37}$ Do współzawodnictwa pracy na wsi wezwano w czasie Ogólnopolskiego Krajowego Zjazdu Robotników i Pracowników Państwowych Gospodarstw Rolnych w Szczecinie (17-19.12.1947 r.), M. Nadolski, Komuniści wobec chtopów..., s. 225.

38 „Ruch współzawodnictwa na wsi przyjął w naszym województwie szerokie rozmiary już jesienią ubiegłego roku. Dzięki temu wykonano wówczas nie tylko z nadwyżką siew ozimin, lecz przeprowadzono orki omal na całym obszarze przeznaczonym pod siew wiosenny", A. Perłowski, Należy zwiększyć tempo przygotowań do żniw. Siewy dobiegają końca, „Głos Szczeciński” wyd. A, 6.05.1949, nr 35, s. 3. O współzawodnictwie w PGR-ach także w artykułach: S. Mioduszewski, Na drodze wspólzawodnictwa i awansu społecznego. PGR-y w przededniu zbiorów, „Głos Szczeciński” wyd. A, 13.07.1949, nr 102, s. 4; B. Lewandowski, Dziś lepiej niż wczoraj-jutro lepiej niż dziś - oto hasto robotników zespołu PGR Oleśnica. Mechanik Kalistrat Mróz odznaczony Orderem Sztandaru Pracy, „Głos Szczeciński” wyd. A, 8.10.1949, nr 189, s. 4; M. Halski, PGR Karsko - dobry sasiad gromady, „Głos Szczeciński” wyd. A, 24.01.1950, nr 24, s. 4; Zorganizowane współzawodnictwo pracy pomoże zakończyć jak najszybciej siewy w PGR Wrzosowo, „Głos Szczeciński” wyd. A, 24.03.1950, nr 83, s. 3; S. Pawłowicz, PGR Batowo przygotowuje się do żniw, 
dukcyjnych ${ }^{39}$. Te ze spółdzielni produkcyjnych, które osiągały najlepsze wyniki, były chwalone przez przedstawicieli władz partyjnych i państwowych. W maju 1949 roku na taką pochwałę zasłużył, w opinii starosty łobeskiego Bronisława Misztala, Zespół Radzim. Według relacji dziennikarza dumni ze swych osiągnięć mieli być także jego pracownicy. Konkretnie ci, którzy byli zatrudnieni w majątku Wołkowo. Zapewniali oni o swojej dumie z tytułu zdobycia sztandaru wspótzawodnictwa, co dla nich wszystkich miało stać się źródtem radości i dobrobytu $^{40}$. Wzorem właściwie gospodarującego socjalistycznego gospodarstwa miały być także: PGR w Witnicy (pow. Chojna) ${ }^{41}$, Zespół Oleszno (pow. Drawsko) ${ }^{42}$ i spółdzielnia produkcyjna w Kani (pow. Stargard) ${ }^{43}$. Dobrze działające spółdzielnie produkcyjne i PGR-y stawiano za wzór tym, w których istniały problemy ${ }^{44}$.

„Głos Szczeciński” wyd. A, 10.06.1950, nr 158, s. 3; Zespół PGR Chlebówek realizuje wytyczne Planu 6-letniego, „Głos Szczeciński” wyd. B, 27.10.1950, nr 296, s. 4; Aby PGR-y produkowaty dużo, dobrze i tanio, „Głos Szczeciński” wyd. C, 8.04.1953, nr 84, s. 3.

39 Spółdzielcy mieli, według „Głosu Szczecińskiego”, rozumieć znaczenie tej rywalizacji, stąd wezwania do niej witane były z entuzjazmem. Tak miało być w trakcie powiatowego zjazdu spółdzielczego w Myśliborzu 7.03.1952 r., SPÓEDZIELNIE powiatu myśliborskiego walcza o wysoki plon, „Głos Szczeciński” wyd. C, 11.03.1952, nr 61, s. 4. O współzawodnictwie pracy w spółdzielniach także w artykułach: Z. Guzik, Rolniczy Zespót Spółdzielczy w Bynowie wzywa do wspótzawodnictwa, „Głos Szczeciński” wyd. A, 11.03.1950, nr 70, s. 4; L. Foszcz, $W$ ślad za Bynowem podejmuje współzawodnictwo spółdzielnia produkcyjna w Łęczycy. Traktorzyści POM pomagaja spółdzielcom, „Głos Szczeciński” wyd. A, 31.03.1950, nr 90, s. 3.

${ }^{40}$ W Wołkowie,,wystrzeliło” żyto, bo Michat Barecki dobrze obsiat rolę wołkami, „Głos Szczeciński" wyd. A, 22.05.1949, nr 51, s. 4.

${ }^{41}$ J. Ruderman, Jak żyją i pracują ludzie przodującego PGR w Witnicy, „Głos Szczeciński” wyd. A, 27.09.1949, nr 116, s. 4.

${ }^{42}$ M. Halski, Zespół Oleśnica odnosi zwycięstwa, „Głos Szczeciński” wyd. A, 16.10.1949, nr 197, s. 4.

${ }^{43}$ Zanim chłopi podpisali statut. Rośnie liczba członków spółdzielni produkcyjnej wsi Kania, „Głos Szczeciński” wyd. A, 31.01.1950, nr 31, s. 4; S. Pawłowicz, Kania idzie ku nowym zwycięstwom, „Głos Szczeciński” wyd. A, 3.02.1950, nr 34, s. 4; S. Pawłowicz, Siewy w Kani trwaty tylko siedem dni, „Głos Szczeciński” wyd. A, 18.04.1950, nr 106, s. 4; E. Możejko, Zobaczyli na własne oczy. Chłopi lubelscy z wycieczka u spółdzielców, „Głos Szczeciński” wyd. C, 11.12.1952, nr 296, s. 4.

44 „Trzeba, by Nowelin stał się wzorem i przykładem dla tych PGR-ów, których kierownictwa usiłują wytłumaczyć swoją niezaradność, brak poczucia odpowiedzialności za powierzony im odcinek naszej gospodarki socjalistycznej »niesprzyjającymi warunkami atmosferycznymi«, brakiem ludzi do pracy, »złą pogodą«”, cyt. za O PGR Nowelin i jego socjalistycznej załodze, „Głos Szczeciński” wyd. C, 9.09.1952, nr 216, s. 4; „Warto aby za przykładem spółdzielców z Wierzbięcina zrobili uczciwy obrachunek i spółdzielcy w Kościuszkach, Strzelewie i innych RZS-ach, które ociągają się z wykonaniem obowiązków wobec państwa”, cyt. za Spółdzielczy obrachunek, „Głos Szczeciński” wyd. C, 27.10.1953, nr 258, s. 4. 
Propagowano też dokonania przodowników pracy, którzy mieli stanowić pozytywny wzór osobowy dla innych ${ }^{45}$. Jeśli więc Danowo mogło być nazwane, zdaniem jednego z dziennikarzy, „perłą w okręgu szczecińskiego P.G.R.”, to nie powinno nikogo dziwić, skoro na czele tego majątku stał „tow. Brożek, przodownik pracy - wzorowy rządca" ${ }^{\text {46 }}$. W majątku Wołkowo (Zespół Radzim) takim wzorcem dla innych w maju 1949 roku miał być też rolnik przekraczający $160 \%$ normy podczas uprawy roli wołami. Owe osiągnięcia miały być możliwe, ponieważ pracownik ten dbał o trzy powierzone jego opiece zwierzęta jak o „rodzonego brata"47. Za fakt nader pozytywny uznawano zgłoszenie gotowości przekroczenia przewidzianego planu produkcyjnego ${ }^{48}$. Stale zachęcano spółdzielców do tego, aby pogłębiali kolektywne sposoby gospodarowania ${ }^{49}$, a pracowników PGR-ów wzywano, aby uczynili: ,z państwowych gospodarstw rolnych wzorowe bazy socjalistycznej gospodarki" ${ }^{{ }^{50}}$.

W całym procesie przeobrażeń socjalistycznych kluczową rolę do odegrania miał naturalnie PZPR. Dowodzono na łamach „Głosu Szczecińskiego”: „od organizacji partyjnej, od osobistego przykładu partyjnych, od niesionych przez nich

45 „Przodownicy pracy Babinka, Lubicza, czy Witnicy - to żołnierze wielkiej armii obrońców pokoju, a kombajn, traktor i kosa w ich dłoni - to potężny oręż w walce o pokój”, cyt. za Zespót PGR Babinek pierwszy zakończył żniwa 7150 wozów w ciagu 16 dni, „Głos Szczeciński” wyd. A, 12.08.1949, nr 132, s. 6. O przodownikach pracy także w artykule M. Halski, Przodownicy pracy PGR awangarda socjalizmu na wsi, „Głos Szczeciński” wyd. A, 27.10.1949, nr 208, s. 3.

${ }^{46}$ W Danowie, Tarnowie i Mostach... Wędrówka po majątkach PGR Pomorza Szczecińskiego, „Głos Szczeciński” wyd. A, 11.05.1949, nr 40, s. 4.

${ }^{47} \mathrm{~W}$ tym samym majątku za godne pochwały uznano także osiągnięcia spółdzielcy określonego mianem naszego ,koniarza”. Jego dokonania zostały należycie docenione. Według relacji dziennikarza otrzymał on premię pieniężną i skierowanie na bezpłatne wczasy do Zakopanego, W Wotkowie..., s. 4.

48 Jako przykład właściwej postawy wskazywano brygadzistę grupy warzywniczo-ogrodowej ze spółdzielni „Wspólny Siew” w Kani, który w trakcie wizyty przewodniczących 70 spółdzielni powiatu miał zanegować plan przyjęty przez Zarząd i obiecać większe zbiory pomidorów (300 q zamiast 225 q) selerów, wczesnej kapusty i wczesnych ziemniaków, A. Perłowski, Wielki dzień „Wspólnego siewu”, „Głos Szczeciński” wyd. C, 15.03.1951, nr 73, s. 4.

${ }^{49}$ S. Pawłowicz, Koń członka spółdzielni Płóciennik-jest własnościa wszystkich udziałowców w Karkowie, „Głos Szczeciński” wyd. A, 5.04.1950, nr 95, s. 4; Zrzeszenie Uprawy Ziemi w Białej ma poważne osiagnięcia, „Głos Szczeciński” wyd. C, 23.05.1952, nr 123, s. 3.

${ }^{50}$ Rozwijamy nowe formy gospodarki. W sześcioletnim planie szczecińskich PGR, „Głos Szczeciński” wyd. A, 12.12.1949, nr 254, s. 4. O postępie technicznym i organizacyjnym w PGR-ach: S. Pawłowicz, „,Rewolucja ziemniaczana” w Małogoszczy, „Głos Szczeciński” wyd. A, 21.04.1950, nr 109, s. 4; Na ugorach Ziemomyśla powstaje nowy zespót PGR, „Głos Szczeciński” wyd. A, 13.05.1950, nr 131, s. 6; Otwarcie nowej suszarni w PGR Benice, „Głos Szczeciński” wyd. A, 16.06.1950, nr 164, s. 4. 
w masy słów prawdy zależy zwycięstwo w walce o pełna realizację obowiązków pracującego chłopstwa wobec państwa" ${ }^{51}$. W jednym z artykułów określono organizacje partyjne mianem: ,aktywnego motoru wszystkich poczynań”52. Zarazem wyzywano często do poprawy ich działalności ${ }^{53}$. Jeśli pojawiały się jakieś niedociągnięcia, to ich przyczyny szukano zwykle w braku właściwego działania ze strony aktywu PZPR ${ }^{54}$. Na przykład aktywiści partyjni w Zamęcinie zawinili tym, zdaniem reportera, że zbyt mało uwagi poświęcali takim zagadnieniom, jak szeroki rozwój hodowli czy wprowadzenie nowoczesnych metod uprawy ziemi ${ }^{55}$.

${ }^{51}$ Organizacja partyjna $w$ Świeszewie prowadzi ofensywę, „Głos Szczeciński” wyd. C, 21.10.1953, nr 253, s. 4.

${ }^{52}$ Dobry aktyw - dobra gospodarka Dalno, zespót gigant ma daleko idace ambicje. Robotnicy gospodarza w PGR-ach, „Głos Szczeciński” wyd. A, 28.05.1949, nr 57, s. 6. O wiodacej roli organizacji partyjnych $\mathrm{w}$ uspołecznionych gospodarstwach rolnych pisano w artykułach: B. Lewandowski, Zespołowa organizacja partyjna - motorem naszych osiagnięć. PGR Pakotulsko wykonało plan zasiewów i wykopek, „Głos Szczeciński” wyd. A, 3.11.1949, nr 215, s. 4; S. Pawłowicz, Organizacja partyjna opracowała plany i kontroluje ich wykonanie. PGR Matkociny przed siewami, „Głos Szczeciński” wyd. A, 17.03.1950, nr 76, s. 4; L. Foszcz, Kursy partyjne pomogły towarzyszom z Zarańska skutecznie walczyć o lepsza organizację $i$ wydajność pracy, „Głos Szczeciński” wyd. A, 18.05.1950, nr 136, s. 4; Chłopi z gromady Mosina zorganizowali Rolniczy Zespót Spółdzielczy. Pod kierownictwem Gromadzkiej Organizacji Partyjnej zwyciężyliśmy w walce klasowej o spóldzielczość produkcyjna, „Głos Szczeciński” wyd. A, 1950, nr 197, s. 5; Zadania szczecińskiej organizacji partyjnej $w$ dziedzinie umocnienia i dalszego rozwoju spótdzielczości produkcyjnej. Referat Egzekutywy $K W$ wygłoszony przez sekretarza $K W$ tow. ... na Plenum Komitetu Wojewódzkiego PZPR w Szczecinie dnia 10 XII Br., „Głos Szczeciński” wyd. ABC, 14.12.1954, nr 296, s. 3-4; F. Wachowicz, O umocnienie i dalszy rozwój spółdzielni produkcyjnych w województwie szczecińskim. Z problemów IV Plenum KC PZPR, „Głos Szczeciński” wyd. C, 11.08.1955, nr 190, s. 3.

${ }^{53}$ Marian Liberek - kierownik Wydziału Rolnego KW PZPR w Szczecinie przekonywał: „Nie do wszystkich jeszcze naszych ogniw i instancji partyjnych przeniknęło głęboko zrozumienie tej podstawowej prawdy, że nie może być trwałych sukcesów gospodarczych bez systematycznej pracy masowo-politycznej”, M. Liberek, Zadania organizacji partyjnej $w$ walce o umocnienie i rozwój spółdzielczości produkcyjnej, „Głos Szczeciński” wyd. C, 15.02.1953, nr 40, s. 3.

${ }^{54}$ Jeden z nich, Bronisław Drygała - sekretarz organizacji partyjnej w RZS w Resku - poddał się nawet samokrytyce i obiecał poprawę: „Zrozumieliśmy, że styl pracy naszej organizacji partyjnej był niewłaściwy i to było powodem wielu błędów: nie było podziału pracy, towarzysze nie byli odpowiedzialni za poszczególne odcinki pracy”, B. Drygała, Czego nauczył nas rok wspólnej gospodarki, „Głos Szczeciński” wyd. C, 30.01.1951, nr 29, s. 4. O tym, że aktywiści partyjni powinni być odpowiedzialni za konkretny odcinek produkcji była także mowa w artykułach: $N A$ RADA aktywu PGR województwa szczecińskiego, „Głos Szczeciński” wyd. C, 16.02.1953, nr 41, s. 1-2; B. Lewandowski, Na przykładzie PGR Strapie, „Głos Szczeciński” wyd. C, 26.03.1953, nr 74, s. 5; Członek partii winien wykonywać określone zadania partyjne, „Głos Szczeciński” wyd. C, 23.06.1953, nr 149 s. 3.

${ }^{55}$ By zamęcińscy spółdzielcy stali się bojowym kolektywem, „Głos Szczeciński” wyd. C, 6.08 .1952 , nr 187, s. 4. Zarzuty formułowano także pod adresem aktywu Zespołu PGR Bytowo (brak zainteresowania zagadnieniami produkcyjnymi) i PGR Zelmowo (brak propagandy na rzecz 
Na łamach „Głosu Szczecińskiego” dowodzono też, że działacze PZPR powinni liczyć na działaczy Zjednoczonego Stronnictwa Ludowego, bowiem: „Dawno poszły w niepamięć niesnaski, które próbował wywołać wróg między członkami PZPR a ZSL" $"$.

Budowa społeczeństwa socjalistycznego powinna w zgodzie z panującą w Polsce Ludowej ideologią prowadzić do ukształtowania się człowieka pracy nowego typu. Osiągnięciu tego celu mógł służyć postęp kulturalny, do czego dochodziło, a publicystyka „Głosu Szczecińskiego” tego dowodziła. Przykładem mogły być stosunki panujące w PGR Mełstowo ${ }^{57}$ i PGR Osowo ${ }^{58}$. Przejście na socjalistyczne sposoby gospodarowania powinno wiązać się także z poprawą życia ludzi pracy. Publicyści „Głosu Szczecińskiego” dowodzili, że tak właśnie się stało w spółdzielniach produkcyjnych i państwowych gospodarstwach rolnych Pomorza Zachodniego ${ }^{59}$. Nie tylko jednak poprawa warunków socjalnych miała decydować o zadowoleniu ze swojego losu pracowników państwowych gospodarstw rolnych i członków spółdzielni produkcyjnych. Ludzie ci, jak utrzymywała ówczesna propaganda, mieli czuć się współwłaścicielami ${ }^{60}$. Powstanie spółdzielni produkcyjnych miało też umożliwić rzeszom biednych chłopów awans społeczny. Życie członka spółdzielni produkcyjnej miało być bez porównania lepsze od doli

współzawodnictwa pracy, np. gazetek ściennych i tablic współzawodnictwa). L. Foszcz, Zespót PGR Bytowo zaniedbuje przygotowania do żniw. Organizacja Partyjna i Rolna Rada Zakładowa mało interesuja się zagadnieniami produkcyjnymi, „Głos Szczeciński” wyd. A, 14.06.1950, nr 162, s. 3; Współzawodnictwo nie kończy się na podejmowaniu zobowiązań. Towarzyszom z zespołu PGR Zelmowo, „Głos Szczeciński” wyd. C, 10.04.1953, nr 86, s. 3.

${ }^{56}$ B. Rędzioch, Organizacja partyjna PZPR i koło ZSL, walcza o rozwój spółdzielni produkcyjnej w Brudzowicach, „Głos Szczeciński” wyd. C, 1.06.1952, nr 130, s. 3; o współdziałaniu ZSL z PZPR także w artykule: Zdecydowanie walczyć będziemy o spółdzielczość produkcyjna we wsi szczecińskiej - stwierdzają delegaci na Wojewódzki Pierwszy Zjazd ZSL w Szczecinie, „Głos Szczeciński” wyd. A, 19.05.1950, nr 137, s. 3.

${ }^{57}$ Działalność tamtejszej świetlicy sprawiła według relacji z czerwca 1949 r., że jego pracownicy zapoznali się z dziełami wielkich poetów polskich i rosyjskich, Mamy dobrą świetlice i... egzotycznego przodownika pracy: Hassana. W zespole PGR Metstowo, „Głos Szczeciński” wyd. A, 11.06.1949, nr 70, s. 6 .

58 Jego pracownice miały stwierdzić: „Pokochałyśmy nasz PGR - opowiadają obie. - Dobrze nam tu. Mamy świetlicę, książki, wszystko czego potrzeba młodemu człowiekowi do spokojnego odpoczynku po pracy. Przodujący ludzie PGR-ów”, „Głos Szczeciński” wyd. C, 25.03.1952, nr 73, s. 6.

${ }^{59}$ L. Springer, Życie gospodarcze..., s. 50.

${ }^{60}$ „Mosty są jego i tysięcy innych robotniczych i chłopskich dzieci”, cyt. za W Danowie..., s. 4; „dziś troskliwie opiekując się pisklętami w powierzonej jej pieczy nowozorganizowanej fermie drobiu mówi »maleństwa, trzeba o nie dbać, bo to przecie nasze wspólne bogactwo «", cyt. za Spółdzielcy z Marwic zrozumieli, „Głos Szczeciński” wyd. C, 18.06.1953, nr 145, s. 3. 
chłopa w Polsce okresu międzywojennego ${ }^{61}$. W jednym z artykułów pisano o życiowym awansie przewodniczącego spółdzielni produkcyjnej w Rzecku (powiat Choszczno), który do 1939 roku był komornikiem wyzyskiwanym przez kułaków, a wiosną 1952 roku był: „,współwłaścicielem dużego 200 hektarowego gospodarstwa spółdzielczego" ${ }^{62}$. Podobne historie opisywano w innych artykułach ${ }^{63}$. Zdaniem B. Kaliskiego owa gotowość władzy ludowej do awansowania ludzi pochodzących z najbiedniejszych warstw społecznych wiązała się z przekonaniem, że będą oni jej bezgranicznie wierni ${ }^{64}$. Obok ludzi ze społecznych nizin liczono też na inne grupy społeczne. Propaganda partyjna chętnie kojarzyła przeobrażenia socjalistyczne z dowartościowaniem na wsi kobiet i młodzieży, oraz z poprawą doli dzieci65.

${ }^{61}$ „Pracowałam ciężko u obszarnika przed wojną - mówiła - i u Niemca w czasie okupacji, a dziś robię na swoim Spółdzielczym. Mój syn, któremu nie mogłam dać więcej wykształcenia jak 3 klasy szkoły podstawowej, dziś uczy się na Uniwersytecie Powszechnym, ma wszędzie otwartą drogę", Z. Guzik, Tych, którzy nie rozumieja, nauczymy, tych co nie wierza przekonamy, wrogów unieszkodliwimy. Spółdzielcy z Bynowa realizuja podjęte zobowiązania, „Głos Szczeciński” wyd. A, 2.04.1950, nr 92, s. 3.

${ }^{62}$ B. Rędzioch, RZS w Rzecku Starym gospodarzy po nowemu, „Głos Szczeciński” wyd. C, 27.05.1952, nr 126, s. 3.

${ }^{63} \mathrm{~W}$ reportażu poświęconym Żabowowi pojawił się też charakterystyczny dla publicystyki „Głosu Szczecińskiego" pozytywny wzór osobowy. W wielu spółdzielniach i PGR-ach takimi postaciami byli przodownicy pracy, a w wypadku tego zespołu - jego dyrektor. To w znacznej mierze cechująca go troska o człowieka miała umożliwić postęp. Podkreślano przy tym jego właściwe pochodzenie społeczne. Przed wojną miał być on biednym człowiekiem, którego trudny los uwrażliwił na problemy ludzi pracy: „Tow. Niewiadomski zanim został dyrektorem zespołu Żabów zwiedził całą prawie Polskę i połowę Niemiec, korzystał z przedwojennej »wolności«, która przecież nikomu nie broniła bez końca i bez rezultatu szukać pracy po całym świecie", cyt. za W Żabowie troszcza się o ludzi, „Głos Szczeciński” wyd. C, 25.03.1952, nr 73, s. 6. Patrz też: Patrzac na tysiac gromad, „Głos Szczeciński” wyd. C, 31.07-1.08.1954, nr 180, s. 3; Przewodniczacy RZS „Głos Szczeciński”, wyd. C, 19.08.1954, nr 196, s. 3.

${ }^{64}$ B. Kaliski B., Przetracić kark kułakowi..., s. 316.

${ }^{65}$ Praca kobiet zadecyduje o wysokich plonach RZS we Włodarce, „Głos Szczeciński” wyd. C, 18.06.1952, nr 145, s. 4. Wśród kobiet szukano wzorów osobowych, takich jak młoda pani agronom z POM w Resku, która z zapałem uczyła spółdzielców z Gostymina nowoczesnych metod uprawy ziemi, czy przodownice pracy ze spółdzielni Trzebórza, Agronom, który uczy spółdzielców, „Głos Szczeciński” wyd. C, 12.02.1952, nr 37, s. 4; PIERWSZY wspólny dochód spółdzielców z Trzebó$r z a$, „Głos Szczeciński” wyd. C, 2.03.1956, nr 53, s. 3.

Przykładem pochwał pod adresem ideowej młodzieży mogą być artykuły o: młodzieżowej spółdzielni produkcyjnej w Witkowie, spółdzielni produkcyjnej „Młody Przodownik”, załodze PGR Czatoryja (złożoną z 37 zetempowców) i młodych spółdzielcach z Krzemiennej (pow. Nowogard), S. Pawłowicz, Zwycięskim krokiem idziemy w słoneczny świt. Młodzieżowa spółdzielnia produkcyjna w Witkowie, „Głos Szczeciński” wyd. A, 18.12.1949, nr 260, s. 5; S. Pawłowicz, Rok zwycięstw młodego Witkowa, „Głos Szczeciński” wyd. A, 28.03.1950, nr 87, s. 3; Nowymi torami poszła praca w spółdzielni produkcyjnej „,Młody Przodownik” po usunięciu z niej nierobów 
Gospodarka zespołowa, zgodnie z ówczesną propagandą, prowadzić miała do upowszechnienia maszyn w rolnictwie. Spółdzielnie nie mogły być, w myśl obowiązujących przepisów, ich właścicielami. Skazane były na korzystanie z usług państwowych ośrodków maszynowych (POM) ${ }^{66}$, które teoretycznie powinny wspierać także indywidualnych rolników. W rzeczywistości działania POM-ów koncentrowały się na pracach wykonywanych na rzecz spółdzielni, a i w tym wypadku efekty ich pracy pozostawiały wiele do życzenia. Pomowskie maszyny często ulegały awariom ${ }^{67}$. W działalności państwowych ośrodków maszynowych dostrzegano także inne niedociągnięcia ${ }^{68}$.

W propagandzie ważną rolę odgrywał wróg klasowy, którego działalność tłumaczyła problemy, na jakie napotykał proces socjalistycznych przeobrażeń. Taką rolę odgrywali, według publicystów „Głosu Szczecińskiego”, zamożni rolnicy, których określano, tak jak w Związku Radzieckim, mianem kułaków ${ }^{69}$. Uświadomieni klasowo spółdzielcy dostrzegać mieli analogię pomiędzy sytuacją w Polsce Ludowej a w ZSRR. W jednym z artykułów, w trakcie rozmowy na temat ksiązki Józefa Stalina, poświęconej zagadnieniu spółdzielczości, padło stwierdzenie: „Tow. Stalin tak napisał jak by tu u nas był. Nie ma już u nas teraz głodu, ale czy żeśmy u nas w naszej spółdzielni nie musieli walczyć z kułakami i ich kumotrami" ${ }^{70}$.

$i$ wichrzycieli, „Głos Szczeciński” wyd. A, 27.05.1950, nr 145, s. 6; Czatoria, młodość socjalistycznej wsi, „Głos Szczeciński” wyd. C, 16.07.1952, nr 169, s. 4; E. Możejko, Spółdzielcy z Krzemiennej gospodaruja z ,planem w ręku”, „Głos Szczeciński” wyd. C, 17.04.1953, nr 92, s. 4.

Przytaczano skargę dziecka indywidualnego rolnika: „Bo tak się nie chce rano wstawać do pasienia krówek, a potem w szkole zawsze ziewam, że aż wstyd. Po lekcjach dzieci ze spółdzielni się bawią, a ja znowu idę za krówkami, jak jaka sierota”, cyt. za Decyzja Mikołaja Suszki, „Głos Szczeciński” wyd. C, 2.10.1953, nr 237, s. 3.

${ }^{66}$ H. Słabek, Powikłania polskiej kolektywizacji rolnictwa (1954-1956), „Dzieje Najnowsze” 1986, z. 1, s. 43.

67 „Traktory w krótkim czasie po powrocie z remontu są niezdatne do użytku, wracają z remontu z wymienionymi częściami często bez zegarów”, cyt. za W Danowie..., s. 4; D. Jarosz, Polityka władz..., s. 144; H. Słabek, Powikłania polskiej kolektywizacji..., s. 44.

${ }^{68}$ A. Perłowski, Jeszcze lepiej zorganizować pracę spółdzielczych ośrodków maszynowych, „Głos Szczeciński” wyd. A, 6.07.1949, nr 95, s. 3; S. Pawłowicz, Brygada „lotna” czy stała? Na przykładzie Karcina, „Głos Szczeciński” wyd. C, 18.06.1954, nr 143, s. 4.

${ }^{69}$ Zob. szerzej D. Jarosz, Obraz chłopa w krajowej publicystyce czasopiśmienniczej 19441959, Warszawa 1994, s. 82.

${ }^{70}$ L. Foszcz, Jest tylko jedna droga. W gminie Dębica powstała 7-ma spółdzielnia produkcyj$n a$, „Głos Szczeciński” wyd. B, 28.12.1950, nr 356, s. 4. 
Chociaż wiadomo było, że kułak to chłop zamożny, to jednak brakowało jednoznacznych kryteriów określających, od jakiego poziomu dobrobytu rolnik indywidualny zasługiwał na to miano. Zdaniem B. Kaliskiego nie było to sprawą przypadku, bowiem: ,propaganda potrzebowała wroga nieokreślonego" ${ }^{71}$. Obok zamożności cechować go powinna wrogość do władzy ludowej, a nawet pokoju na świecie ${ }^{72}$, a przede wszystkim gotowość do bogacenia się w sposób nieuczciwy. Kułacy dopuszczać mieli się wielu nadużyć podatkowych i dotyczących obowiązkowych dostaw ${ }^{73}$. Kreowano ich na ludzi bezdusznych i bezwzględnych ${ }^{74}$. Mieli do tej pory żyć kosztem biedaków i dlatego obawiali się kolektywizacji ${ }^{75}$. $\mathrm{Z}$ tej racji kułacy mieli, według „Głosu Szczecińskiego”, prowadzić propagandę mającą na celu uniemożliwienie powstania spółdzielni. W tym celu: „straszyli torbami, głodem, pańszczyzną"76. Gdy to zawiodło, podstępnie mieli przenikać w szeregi spółdzielców, aby ich skłócić. W jednym z artykułów z początku 1952 roku za przejaw wrogiej kułackiej działalności uznano rozsiewanie plotek o niskiej dniówce w spółdzielni (Kunowo), czy próbę zabrania konia ze spółdzielczej stajni (Ińsko), a nawet awanturę wywołaną na zebraniu przez pijanego chłopa (Białuń) ${ }^{77}$.

${ }^{71}$ B. Kaliski, Przetracić kark kułakowi..., s. 307.

72 „Niech przykładowy siew, a później inne prace na spółdzielczych polach, pokażą wszystkim, że nasza zespołowa gospodarka jest lepsza od samotniczej, tak żeby uczciwi gospodarzący jeszcze samotnie mało i średniorolni chłopi to zrozumieli i żeby wyzwolili się od kułaków, którzy są wrogami pokoju", cyt. za WSPÓLNY siew - wielki plon. Dla pokoju i szczęścia naszej ojczyzny. Członkowie spótdzielni produkcyjnej ,WSPÓLNY SIEW” w Kani wzywają do wspótzawodnictwa, „Głos Szczeciński” wyd. C, 15.03.1951, nr 73, s. 1.

${ }^{73} \mathrm{~W}$ jednym z artykułów opublikowanych wiosną 1953 r. opisano praktykę podszywania się zamożnych rolników pod średniaków. Wywiązywali się oni ze swoich obowiązków wobec państwa tylko pozornie. W rzeczywistości bowiem posiadali też ziemię nieujętą w ewidencji, Pomoc nie kończy się z chwila powstania spółdzielni. Z doświadczeń RZS w Karsku Myśliborskim, „Głos Szczeciński” wyd. C, 7.05.1953, nr 109, s. 3; D. Jarosz, Obraz chłopa..., s. 86.

${ }^{74}$ Kiedy jeden z rolników zachorował, to kułacy śmieli się z nieszczęścia swego sąsiada. Na szczęście w zbiorze zbóż pomogli mu spółdzielcy. Dzięki temu cała historia zakończyła się szczęśliwie. Wdzięczny rolnik nie tylko przyłączył się do spółdzielni, ale nawet został jej przewodniczącym: S. Pawłowicz, Członkowie RZS w Smolnicy..., s. 4; D. Jarosz, Obraz chłopa..., s. 85.

${ }^{75}$ Historia - jakich wiele..., „Głos Szczeciński” wyd. C, 22.09.1954, nr 225, s. 3.

${ }^{76}$ E. Możejko, Na nic się nie zdała kułacka propaganda, „Głos Szczeciński” wyd. C, 7.08.1952, nr 188, s. 4; B. Lewandowski, Rolniczy Zespót Spółdzielczy w Szydłowie w walce klasowej buduje lepsza przyszłość, „Głos Szczeciński” wyd. A, 25.02.1950, nr 56, s. 6; D. Jarosz, Obraz chłopa..., s. 86 .

${ }^{77}$ Codziennie trzeba pamiętać o walce z wrogiem klasowym, „Głos Szczeciński” wyd. C, 29.01.1952, nr 25, s. 5. 
Atakować miano zwłaszcza spółdzielnie w powiatach chojeńskim ${ }^{78}$ i gryfickim ${ }^{79}$. Skutecznym środkiem zaradczym miało być usunięcie kułaków ze spółdzielni i oparcie ich na biedocie wiejskiej ${ }^{80}$. Spółdzielnie produkcyjne powinny zresztą współdziałać z drobnymi rolnikami i w ten sposób ich dla siebie zjednywać ${ }^{81}$.

Uświadomieni politycznie spółdzielcy i pracownicy państwowych gospodarstw rolnych dawali wyraz swemu poparciu dla władz przez: masowe uczestnictwo w wyborach i głosowanie na kandydatów Frontu Narodowego, występowanie $\mathrm{w}$ trakcie różnych narad $\mathrm{z}$ wezwaniami o zwiększenie produkcji oraz chwalenie się osiągnięciami swych socjalistycznych gospodarstw ${ }^{82}$. W artykułach poświęconych problemom spółdzielczości i funkcjonowaniu PGR-ów nie zabrakło też charakterystycznego dla okresu stalinizmu kultu ówczesnych przywódców ZSRR i Polski Ludowej ${ }^{83}$.

${ }^{78}$ „Kułacy nie wychodzili do roboty i wpływali w tym kierunku na innych, nie wnosili wkładów paszowych, ani koni, siali kłótnie, rozpijali spółdzielców, rozbijali spółdzielnie od wewnątrz”, A. Perłowski, Gdy toleruje się kułaka... Dlaczego w pow. Chojeńskim nie rośnie ilość spółdzielni produkcyjnych, „Głos Szczeciński” wyd. C, 19.01.1951, nr 18, s. 4.

${ }^{79}$ Opierać się na organizacji partyjnej! Wzmacniaja się spółdzielnie produkcyjne pow. gryfickiego, „Głos Szczeciński” wyd. C, 13.06.1952, nr 141, s. 4.

${ }^{80} W$ oparciu o masy mało i średniorolnych chłopów będziemy rozbudowywać spółdzielczość produkcyjna bez kułaków, wbrew nim i przeciw nim. Wypowiedzi delegatów na wojewódzkiej konferencji aktywu spółdzielni produkcyjnych w Szczecinie, „Głos Szczeciński” wyd. A, 27.06.1950, nr 175, s. 3-4.

${ }^{81}$ S. Pawłowicz, Rolniczy Zespót Spółdzielczy dobry sąsiad małorolnych chłopów. Siewy w Kunowie, „Głos Szczeciński” 18.10.1950, nr 287, s. 4.

${ }^{82}$ E. Parysek, Tak pracowaliśmy przy tegorocznych żniwach, „Głos Szczeciński” wyd. A, 27.08.1949, nr 147, s. 4; E. Możejko, Gromada Mokre razem pracuje $i$ walczy, „Głos Szczeciński” wyd. C, 20-21.09.1952, nr 226, s. 4; UMOCNIMY gospodarke zespołowa zbudujemy setki nowych spółdzielni produkcyjnych. Wojewódzka narada agitatorów i aktywu wiejskiego, „Głos Szczeciński” wyd. C, 29.01.1953, nr 26, s. 1, 3; NA ZJAZDACH powiatowych spółdzielcy województwa szczecińskiego podsumowali swój wielki dorobek i wybrali delegatów na I Krajowy Zjazd Spótdzielni Produkcyjnej w Warszawie, „Głos Szczeciński” wyd. C, 9.02.1953, nr 35, s. 1, 4; POWIATOWY zjazd delegatów w Choszcznie podsumowat osiagnięcia spółdzielni produkcyjnych, „Głos Szczeciński” wyd. C, 16.02.1953, nr 41, s. 1; S. Ciołek, Wielka hodowla - to wielka zamożność, „Głos Szczeciński” wyd. C, 12.05.1954, nr 111, s. 4; J. Pawiński, Jak uczy partia, „Głos Szczeciński” wyd. C, 9.09.1954, nr 214, s. 4; A. Sander, Przygotowujemy się do zimy, „Głos Szczeciński” wyd. C, 1954, nr 240, s. 3; A. Perłowski, Rozważania przedrozliczeniowe, „Głos Szczeciński” wyd. A, 9.12.1954, nr 292, s. 3; Gumienieckie doświadczenia, „Głos Szczeciński” wyd. C, 2-3.04.1955, nr 79, s. 3; L. Więckowska, Z opłotków - na szeroki świat, „Głos Szczeciński” wyd. C, 27.10.1955, nr 256, s. 3; W. Jeny, Nasze perspektywy, „Głos Szczeciński” wyd. C, 13.12.1955, nr 296, s. 3.

${ }^{83}$ Oto przykłady: listu do B. Bieruta spółdzielcy słuchali w ogromnym skupieniu; wykonanie bierutowskiego zobowiązania produkcyjnego to dla spółdzielni sprawa honoru; na wieść o śmierci Józefa Stalina przodownik pracy zapisał się do partii. Spółdzielnia pokoju i przyjaźni, „Głos Szczeciński” wyd. C, 11.03.1952, nr 61, s. 3; Boleszkowice zbieraja pierwsze płody Bierutowskiego 
Komunistyczni propagandyści zdawali sobie sprawę, że odwołanie się wyłącznie do pozytywnych aspektów funkcjonowania tak państwowych gospodarstw rolnych, jak spółdzielni produkcyjnych może cały przekaz czynić całkowicie niewiarygodnym w oczach czytelnika. Wyznaczano więc publicystyce partyjnej określone ramy dla krytyki. Jak zauważył K. Kozłowski, w zgodzie ze wskazaniami władz partyjnych zarówno centralnego, jak i wojewódzkiego szczebla krytykowano problemy w stosunkach międzyludzkich oraz sposób funkcjonowania biurokracji ${ }^{84}$. Z czasem krytyka błędów $i$ wypaczeń nasilała się. Zwracano uwagę na następujące problemy: lekceważenie zasad bezpieczeństwa i higieny pracy ${ }^{85}$, marnotrawstwo ${ }^{86}$, nieprzestrzeganie harmonogramu $\mathrm{prac}^{87}$, niewykonywanie planów produkcyjnych ${ }^{88}$, łamanie statutów spółdzielni przez ich

siewu, „Głos Szczeciński” wyd. C, 27.08.1952, nr 205, s. 3; B. Lewandowski, Wiosenny egzamin Winczyka i towarzyszy z PGR Kołki, „Głos Szczeciński” wyd. C, 9.04.1953, nr 85, s. 3; S. Zgodziński, Nasz PGR pracuje coraz lepiej, „Głos Szczeciński” wyd. C, 8.07.1953, nr 162, s. 3.

${ }^{84}$ K. Kozłowski, Środki masowego..., s. 19. Artykuły, w których podejmowano problem biurokratyzmu w spółdzielniach produkcyjnych i PGR-ach: Tylko dostateczna ilość robotników sezonowych może zagwarantować wykonanie planu gospodarczego PGR. Rok bieżacy będzie rokiem wielkiego urodzaju, „Głos Szczeciński” wyd. A, 17.06.1949, nr 76, s. 3; Walczymy z nieuzasadnionym optymizmem i szkodliwa zasada ,jakoś to będzie”, „Głos Szczeciński” wyd. A, 19.07.1949, nr 108, s. 4; S. Szydłowski, Brak współzawodnictwa pracy w zespole PGR Krzymów - to najpoważniejsza przyczyna niedociagnięć, „Głos Szczeciński” wyd. A, 4.10.1949, nr 185, s. 3; S. Pawłowicz, Rolniczy Zespół Spółdzielczy „Pług i sierp” w Ustowie sumuje wyniki rocznej pracy, „Głos Szczeciński” wyd. A, 15.04.1950, nr 103, s. 4; M. Stochmal, W zespole PGR Bukowo Człuchowskie potrzebni sq nowi ludzie - nowe kadry! - pisze nasz korespondent robotniczy, „Głos Szczeciński” wyd. A, 28.05.1950, nr 146, s. 4; Zaniedbania i niewykorzystane rezerwy. O brakach w pracy PGR Krześlin, „Głos Szczeciński” wyd. C, 4.11.1952, nr 264, s. 4; E. Możejko, A przecież decyduje czlowiek... O stosunku do spraw i bolaczek ludzkich w PGR Metstowo, „Głos Szczeciński” wyd. C, 12.11.1952, nr 271, s. 4; B. Lewandowski, $O$ „,urawniłowce” $i$ beztroskich „wizytatorach”. Z pobytu w PGR Rakowo, „Głos Szczeciński” wyd. C, 10.12.1952, nr 295, s. 4; Jak wykorzystywane sa w PGR-ach fundusze socjalne, „Głos Szczeciński” wyd. C, 30.12.1952, nr 310, s. 4; E. Możejko, Spółdzielcy z Kolna musza się poczuć gospodarzami, „Głos Szczeciński” wyd. C, 12-13.09.1953, nr 220, s. 3; J. Zbiciński, Wykorzystać kredyty inwestycyjne w spółdzielniach produkcyjnych, „Głos Szczeciński” wyd. C, 11-12.09.1954, nr 216, s. 3; Przesuną́ z marginesu, „Głos Szczeciński” wyd. C, 27.10.1954, nr 255, s. 3; W Lisiem Polu-gromadzie „kułackiej”, „Głos Szczeciński” wyd. A, 23.12.1954, nr 304, s. 4; W. Srokowska, O państwie w państwie $i$ anarchii czyli o PGR-owskiej administracji, „Głos Szczeciński” wyd. C, 16.03.1955, nr 64, s. 3.

${ }^{85}$ B. Chocianowicz, Osiem niepotrzebnych śmierci, „Głos Szczeciński” wyd. C, 21.11.1955, nr 277, s. 3.

${ }^{86}$ O przyczynach opóźnienia i marnotrawstwa rzepaku w PGR Zwierzynek, „Głos Szczeciński” wyd. C, 8.08.1952, nr 189, s. 4.

${ }^{87}$ S. Trzemżalski, Z starych błędów trzeba wyciagnąć naukę, „Głos Szczeciński” wyd. C, 1617.05.1953, nr 117, s. 3.

${ }^{88}$ Bilans Nowielina, „Głos Szczeciński” wyd. ABC, 18-19.12.1954, nr 300, s. 3; B. Ławryszkow, BOLESZKOWICE - dobra spółdzielnia, „Głos Szczeciński” wyd. C, 12.09.1955, nr 217, s. 4. 
kierownictwa ${ }^{89}$, niegospodarność i oszustwa ${ }^{90}$, a także brak współpracy gospodarstw uspołecznionych z uczciwymi średniakami ${ }^{91}$. Wskazywano też na słabe polityczne uświadomienie spółdzielców ${ }^{92}$.

W pierwszej połowie 1956 roku na łamach „Głosu Szczecińskiego” nie sposób znaleźć zapowiedzi rychłego fiaska wielkiego społecznego eksperymentu, jakim była próba kolektywizacji polskiej wsi. Wprawdzie Stanisław Pawłowicz przyznawał, że do roku 1953 wyraźnie słabło tempo powstawania nowych spółdzielni, ale nadal deklarował wiarę w możność ich dynamicznego rozwoju ${ }^{93}$. Jeszcze w czerwcu 1956 roku przytoczono optymistyczną opinię sekretarza KW PZPR w Szczecinie:

Jeśli potrafimy w pełni zabezpieczyć wykonanie planu opracowanego przez plenum KW, jeśli będziemy wykorzystywać bodźce materialne ustalone przez ostatnie uchwały partii i rządu, możliwym będzie zrealizowanie głównego zadania, jakie postawiło przed organizacją szczecińską KW, a mianowicie osiągnięcie do 1960 roku pełnego uspółdzielczenia wsi szczecińskiej i przyciągniecie do spółdzielczości produkcyjnej większości chłopów pracujących ${ }^{94}$.

Koniec roku 1956 przyniósł całkowite załamanie się spółdzielczości produkcyjnej w Polsce. Momentem przełomowym było VIII Plenum KC PZPR (19-21.10.1956 r.), na którym Władysław Gomułka opowiedział się za oparciem spółdzielczości produkcyjnej na zasadach dobrowolności ${ }^{95}$. Spółdzielnie produkcyjne w większości uległy samorozwiązaniu. Zjawisko to było masowe szcze-

${ }^{89}$ J. Klimkiewicz, Spokój i „,kwiatki”, czyli o umacnianiu spółdzielni produkcyjnych, „Głos Szczeciński” wyd. C, 3.10.1955, nr 235, s. 3.

${ }^{90}$ S. Pawłowicz, Te same warunki, a jednak..., „Głos Szczeciński” wyd. C, 17.09.1954, nr 221, s. 3; Trzeba uczciwie i po gospodarsku, „Głos Szczeciński” wyd. C, 14.10.1954, nr 244, s. 4; Cud mniemany - czyli zboże które jest i którego nie ma, „Głos Szczeciński” wyd. ABC, 23.11.1954, nr 278, s. 3; B. Chocianowicz, Przeciw hamulcom i płyciźnie, „Głos Szczeciński” wyd. C, 9.02.1956, nr 34, s. 3 .

${ }^{91}$ O , skrzywionej drodze” i nierozwiniętych skrzydłach, „Głos Szczeciński” wyd. C, 9.06.1953, nr 137, s. 3.

${ }^{92}$ Gdy komitety założycielskie pozostawia się bez pomocy. Na przykładzie powiatu Kamień Pomorski, „Głos Szczeciński” wyd. C, 28.05.1953, nr 127, s. 3; W. Srokowska, Błą i skutki, „Głos Szczeciński” wyd. C, 30.09.1954, nr 232, s. 4.

${ }^{93}$ S. Pawłowicz, Na froncie na razie cisza, „Głos Szczeciński” wyd. C, 8.02.1956, nr 33, s. 3.

${ }^{94}$ B. Nowosad, Plan mamy - trzeba działania, „Głos Szczeciński” wyd. C, 22.06.1956, nr 148, s. 3.

${ }^{95}$ D. Jarosz, Polityka władz..., s. 38; H. Słabek, Powikłania polskiej kolektywizacji.., s. 59. 
gólnie tam, gdzie pozornie spółdzielczość była najsilniejsza, czyli na Ziemiach Odzyskanych, w tym w województwie szczecińskim ${ }^{96}$. Fakt ten pokazał, jak oderwane od rzeczywistości były wszystkie artykuły chwalące osiągnięcia spółdzielni produkcyjnych i państwowych gospodarstw rolnych.

\section{Bibliografia}

\section{Źródła drukowane}

Kozłowski K., Materiaty archiwalne do „Wydarzeń gryfickich” z 1951 r., Szczecin 1992.

\section{Czasopisma}

„Głos Szczeciński” 1949-1956.

\section{Monografie i artykuly}

Białecki T., Czasopiśmiennictwo polskie na Pomorzu Zachodnim w latach 1945-1949, „Przegląd Zachodniopomorski” 1968 z. 4, s. 119-145.

Białecki T., Prasa Pomorza Szczecińskiego w latach 1945-1975, Szczecin 1978.

Białecki T., Prasa szczecińska, w: 25 lat prasy na ziemiach zachodnich i pótnocnych, Kraków 1972, s. 75-94.

Białecki T., Rozwój prasy partyjnej PPR i PZPR w województwie szczecińskim w latach 1945-1972, „Przegląd Zachodniopomorski” 1972, z. 3, s. 185-202.

Dymek B., PZPR 1948-1954, Warszawa 1989.

Jarosz D., Obraz chtopa w krajowej publicystyce czasopiśmienniczej 1944-1959, Warszawa 1994.

Jarosz D., Polityka władz komunistycznych w Polsce w latach 1948-1956 a chtopi, Warszawa 1998.

Kaliński J., Forsowna kolektywizacja rolnictwa (1948-1956), „Kwartalnik Historyczny” 1984, nr 1, s. 111-136.

Kaliski B., Przetracić kark kułakowi... terenowy aparat PZPR wobec kolektywizacji rolnictwa, „Przegląd Powszechny” 2000, nr 6, s. 303-316.

Krasucki E., Początki „,Glosu Szczecińskiego” w świetle dokumentów z lipca 1947 roku, „Przegląd Zachodniopomorski” 2005, z. 3, s. 155-166.

Kozłowski K., Środki masowego przekazu w Szczecinie w latach 1945-1990, w: Stowem i piórem. 50 lat dziennikarstwa na Pomorzu Zachodnim, red. T. Białecki, Szczecin 1996.

Nadolski M., Komuniści wobec chłopów w Polsce 1941-1956. Mity i rzeczywistość, Warszawa 1993.

${ }^{96}$ 30.09.1956 r. istniało 10203 spółdzielnie, 31 grudnia tego roku było ich już tylko 1528, D. Jarosz, Polityka władz..., s. 152; J. Kaliński, Forsowna kolektywizacja..., s. 135. 
Ożóg M.E., Władysław Gomułka. Biografia polityczna, t. 1, Warszawa 1989.

Pawłowicz S., 40 lat! Głos Szczeciński. Dziennik Polskiej Zjednoczonej Partii Robotniczej 1947-1987, Szczecin 1987.

Słabek H., Powikłania polskiej kolektywizacji rolnictwa (1954-1956), „Dzieje Najnowsze" 1986, z. 1, s. 41-63.

Springer L., Życie gospodarcze regionu szczecińskiego na łamach „, Głosu Szczecińskiego” w jego ostatnim stalinowskim okresie, „Przegląd Zachodniopomorski” 2002, z. 3, s. 39-67.

\section{Propaganda of the Achievements of the Productive Cooperatives and State Agricultural Farms in the Newspaper "Glos Szczeciński" up to 1956, as an Example of the Communist Indoctrination of the Polish Community in West Pomerania}

\section{SUMmaRY}

The article deals with the communist propaganda, which was supposed to convince the readers of the advantages of productive cooperatives and state agricultural farms during the period of intensive collectivisation of the Polish villages. 'Głos Szczeciński' was a newspaper that played a very special role in the communist propaganda in West Pomerania. The Polish community was indoctrinated there through a manipulated image of the reality presented in documentaries, commentaries and reports of the party's and state's bodies. The articles published in 'Głos Szczeciński' dealt with such problems as the creation of new cooperatives, the completion of production plans, work competition, the role of the party and the fight against the kulaks (Russian: кула́к). 